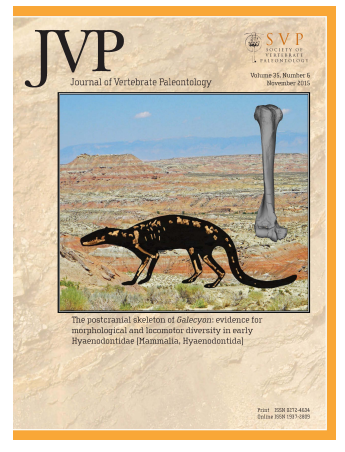

Journal of Vertebrate Paleontology

ISSN: 0272-4634 (Print) 1937-2809 (Online) Journal homepage: http://www.tandfonline.com/loi/ujvp20

\title{
Alexandronectes zealandiensis gen. et sp. nov., a new aristonectine plesiosaur from the lower Maastrichtian of New Zealand
}

\section{Rodrigo A. Otero, JosÉ P. O'Gorman, Norton Hiller, F. Robin O'Keefe \& R.} Ewan Fordyce

To cite this article: Rodrigo A. Otero, JosÉ P. O'Gorman, Norton Hiller, F. Robin O'Keefe \& R. Ewan Fordyce (2016): Alexandronectes zealandiensis gen. et sp. nov., a new aristonectine plesiosaur from the lower Maastrichtian of New Zealand, Journal of Vertebrate Paleontology

To link to this article: http://dx.doi.org/10.1080/02724634.2015.1054494

View supplementary material $\widetilde{ }$

Published online: 14 Jan 2016.

Submit your article to this journal ¿

Q View related articles $\sqsubset$

View Crossmark data \lceil 


\title{
ALEXANDRONECTES ZEALANDIENSIS GEN. ET SP. NOV., A NEW ARISTONECTINE PLESIOSAUR FROM THE LOWER MAASTRICHTIAN OF NEW ZEALAND
}

\author{
RODRIGO A. OTERO, ${ }^{* 1}$ JOSÉ P. O'GORMAN, ${ }^{2,3}{ }^{\prime 2}$ ORTON HILLER, ${ }^{4,5}$ F. ROBIN O'KEEFE, ${ }^{6}$ and R. EWAN FORDYCE ${ }^{7}$ \\ ${ }^{1}$ Red Paleontológica U-Chile, Laboratorio de Ontogenia y Filogenia, Departamento de Biología, Facultad de Ciencias, Universidad \\ de Chile, Las Palmeras 3425, Santiago, Chile, otero2112@gmail.com; \\ ${ }^{2}$ División Paleontología Vertebrados, Museo de La Plata, Universidad Nacional de La Plata, Paseo del Bosque s/n., B1900FWA \\ La Plata, Argentina; \\ ${ }^{3}$ CONICET, Consejo Nacional de Investigaciones Científicas y Técnicas, Argentina, joseogorman@fcnym.unlp.edu.ar; \\ ${ }^{4}$ Department of Geological Sciences, University of Canterbury, PB 4800, Christchurch 8140, New Zealand; \\ ${ }^{5}$ Canterbury Museum, Rolleston Avenue, Christchurch 8013, New Zealand, norton.hiller@canterbury.ac.nz; \\ ${ }^{6}$ Department of Biological Sciences, Marshall University, Huntington, West Virginia 25755, U.S.A., okeefef@marshall.edu; \\ ${ }^{7}$ Department of Geology, University of Otago, Dunedin, 9054, New Zealand, ewan.fordyce@otago.ac.nz
}

\begin{abstract}
A fragmentary plesiosaur skull from lower Maastrichtian levels of the Conway Formation, New Zealand, is redescribed. Originally regarded as pertaining to two separate individuals, we argue that they represent a single individual belonging to a new aristonectine elasmosaurid, Alexandronectes zealandiensis gen. et sp. nov. This new taxon has common morphologies with other aristonectines such as expansion of the pterygoids extending posteriorly beyond the occipital condyle (as observed in Ar. quiriquinensis and probably in Kaiwhekea katiki) and the presence of an 'A'-shaped squamosal arch in dorsal view. Otherwise, it is distinguished from these latter species by having different paraoccipital processes, a different mandibular glenoid, and an adult skull comparatively smaller than $K$. katiki and Aristonectes spp. The new taxon is a morphologically intermediate form between the dorsoventrally high skull of $K$. katiki and the mediolaterally expanded skulls of Aristonectes spp. The studied specimen is the second genus and species and the third report of an aristonectine recovered from lower Maastrichtian beds of New Zealand, emphasizing the diversity of this group in New Zealand and also indicating that aristonectines could include smaller species than those already known.
\end{abstract}

http://zoobank.org/urn:lsid:zoobank.org:pub:5167B8FB-82F7-4F33-8663-EBF16692A9A0

SUPPLEMENTAL DATA—Supplemental materials are available for this article for free at www.tandfonline.com/UJVP

Citation for this article: Otero, R. A., J. P. O'Gorman, N. Hiller, F. R. O'Keefe, and R. E. Fordyce. 2016. Alexandronectes zealandiensis gen. et sp. nov., a new aristonectine plesiosaur from the lower Maastrichtian of New Zealand. Journal of Vertebrate Paleontology. DOI: 10.1080/02724634.2015.1054494.

\section{INTRODUCTION}

Aristonectines (O'Keefe and Street, 2009; sensu Otero et al., 2012) are a monophyletic clade of highly derived, Late Cretaceous austral elasmosaurid plesiosaurs (Diapsida, Sauropterygia) characterized by relatively large skulls $(70-90 \mathrm{~cm})$, as well as by features of the axial skeleton, including shortened cervical centra (Chatterjee and Small, 1989; Cruickshank and Fordyce, 2002; Gasparini et al., 2003b; Otero et al., 2014b). So far, Kaiwhekea katiki is the only aristonectine from New Zealand identified to species level. A second coeval specimen from New Zealand is regarded as an indeterminate aristonectine (O'Gorman et al., 2014b). Known aristonectines are represented in three main regions within the Weddellian Biogeographic Province (sensu Zinsmeister, 1979), with records from southern South America, the James Ross Basin in the Antarctic Peninsula, and New Zealand (Chatterjee and Small, 1989; Cruickshank and Fordyce, 2002; Gasparini et al., 2003b; O'Gorman et al., 2013; Otero et al., 2014a, b).

The Late Cretaceous plesiosaur record from New Zealand is rich and so far includes several elasmosaurid genera and species, although most of the historical taxa are currently considered

*Corresponding author. nomina dubia (Welles and Gregg [1971] and references therein). However, this record includes the aristonectine Kaiwhekea katiki Cruickshank and Fordyce, 2002, known by a unique, fairly complete skeleton from lower Maastrichtian levels exposed at Shag Point, north of Dunedin. Non-aristonectine elasmosaurids are represented by Tuarangisaurus keyesi Wiffen and Moisley, 1986, from the Campanian-Maastrichtian of Mangahouanga Stream, Hawkes Bay, known from a nearly complete skull and several anterior cervical vertebrae, and Mauisaurus haasti Hector, 1874, from the middle Campanian of Jed River, North Canterbury (Wilson et al., 2005). Mauisaurus haasti was originally based on several specimens and later emended by Welles and Gregg (1971). Welles (1952) designated the specimen DM R1529 as the lectotype of the species, and the remaining material, as well as other new specimens, were left as referred specimens. Later, a fairly complete skeleton (CM Zfr 115) from late Campanian beds at Ngaroma Station, north of Christchurch, was assigned to M. haasti by Hiller et al. (2005). Indeterminate polycotylids as well as 'pliosaurids' sensu lato have also been mentioned (Welles and Gregg, 1971; Wiffen and Moisley, 1986).

This article presents a redescription of an incomplete skull, previously described by Hiller and Mannering (2004). Prior to 2004, this specimen was regarded as two separate individuals and was curiously left out of the extensive review of Late Cretaceous 
marine reptiles from New Zealand carried out by Welles and Gregg (1971). According to the catalogue entries in the Canterbury Museum where the material is housed, the remains were found before 1888. The two skull fragments (CM Zfr 73 and CM Zfr 91) were compared in anatomy, size, preservation, mineralization, and deformation pattern. Being the same in all respects, they are here considered as belonging to a single individual, as initially suggested by Hiller and Mannering (2004). Several unique morphological characters are now observed and compared for the first time with skull material from Upper Cretaceous beds exposed elsewhere, particularly from New Zealand, Antarctica, Argentina, and Chile, allowing the identification of a new genus and species, revealing new diagnostic features of the aristonectines, and expanding the diversity of Late Cretaceous elasmosaurids from New Zealand.

Anatomical Abbreviations_-aa, atlas-axis; af, adductor fossa; an, angular; ba, basal articulation; bes, basioccipital/exoccipitalopisthotic suture; boc, basioccipital; bot, basioccipital tuberosity; bs, basisphenoid; ccf, concave facet of the paraoccipital process; cvf, convex facet of the paraoccipital process; dep, depression; dpp, dorsal process of the pterygoid; ds, dorsum sellae; ect, ectopterygoid; fm, foramen magnum; fo, fenestra ovalis; fps, facet for the parasphenoid; fpt, facets for the pterygoid; gl, glenoid cavity; i, indeterminate; icf, internal carotid foramen; $\mathbf{I X}+\mathbf{X}$, jugular foramen (glossopharyngeal and vagus nerves and posterior branch of the jugular vein); leo, left exoccipital-opisthotic; Ip, left parietal; lpp, left paraoccipital process; oc, occipital condyle; pep, plate-like posterior extension of pterygoids; pgp, lingual preglenoid process; pi, ventral pit of the basioccipital; pr, prootic; pt, pterygoid; q, quadrate; rac, right adductor chamber; rap, retroarticular process; reo, right exoccipital-opisthotic; rp, right parietal; rpp, right paraoccipital process; san, surangular; so, supraoccipital; sq, squamosal; st, sella turcica; tf, temporal fossa; VI, foramen of the abducens nerve; vr, ventral recesses; XII, foramen of the hypoglossal nerve.

Institutional Abbreviations-CM, Canterbury Museum, Christchurch, New Zealand; DM, former Dominion Museum, now known as Museum of New Zealand Te Papa Tongarewa, Wellington, New Zealand; MLP, Museo de La Plata, Buenos Aires Province, Argentina; NHMUK; Natural History Museum, London, UK; OU, Geology Museum, University of Otago, Dunedin, New Zealand; SGO.PV, Área Paleontología de Vertebrados, Museo Nacional de Historia Natural, Santiago, Chile; TTU P, Museum of Texas Tech University, Lubbock, Texas, U.S.A.

\section{LOCALITY AND GEOLOGIC SETTING}

Based on the historical information available at Canterbury Museum, both portions of the skull (CM Zfr 73 and CM Zfr 91) were probably part of the collections made by Alexander McKay in 1872 from the Waipara River (Welles and Gregg, 1971; Hiller and Mannering, 2004). The exact locality and horizon are uncertain, but the assemblage of dinoflagellate cysts recovered from sedimentary matrix adhering to both skull fragments confirms that the exposures of the Conway Formation along the Waipara River (Fig. 1) are the most likely source of the specimen (Wilson et al. 2005:table 1). In addition, dinoflagellates indicate an early Maastrichtian age for the skull (Alterbidinium acutulum Zone), approximately the middle of the local Upper Haumurian Stage (Wilson et al., 2005:fig. 4).

\section{MATERIAL AND METHODS}

The two specimens CM Zfr 73 and CM Zfr 91 are anatomically complementary, there is no duplication of elements, and both possess an identical mineralization of the bones. Taphonomically, both specimens are crushed and distorted onto their right side. They also match in size and quality of preservation (i.e., no severe erosion or disaggregation of the bony elements) and both were reportedly recovered by the same collector (A. McKay) from a single locality. In addition, the distinctive paroccipital process (see description below) preserved in CM Zfr 73 (left portion of the skull) precisely matches in shape and size that preserved in CM Zfr 91 (right portion of the skull), strongly supporting that both belong to the same individual.

To assist with comparisons, further preparation was carried out during 2014 on the upper Maastrichtian Chilean aristonectine specimen holotype of Aristonectes quiriquinensis Otero, Soto-Acuña, O'Keefe, O'Gorman, Stinnesbeck, Suárez, RubilarRogers, Salazar, and Quinzio, 2014b (SGO.PV.957). This allows evaluation of the morphological features of the CM material studied here. Other comparisons were mainly with taxa from the Weddellian Biogeographic Province (Zinsmeister, 1979). These include the species from New Zealand previously listed, as well as the holotype of Ar. quiriquinensis from the upper Maastrichtian of central Chile, the holotype of Ar. parvidens Cabrera, 1941 (MLP 40-XI-14-6), from the upper Maastrichtian of Argentinean Patagonia, and the holotype TTU P 9219 of 'Morturneria seymourensis' (Chatterjee and Small, 1989; Chatterjee and Creisler, 1994) from the upper Maastrichtian of Antarctica. This specimen has been referred to the genus Aristonectes (Gasparini et al., 2003b), but the material is under review (FRO) and the validity of the taxon needs to be reevaluated. Hereafter, the specimen is referred to by its collection number (TTU P 9219).

To test the affinities of Alexandronectes zealandiensis gen. et sp. nov., a phylogenetic analysis was performed using the data set of O'Keefe and Street (2009) modified by Otero et al. (2014b), with addition of a new character (Character 91, pterygoid-like plates posteriorly extended beyond the occipital condyle; 0 , absent; 1 , present). Character scores of the specimen here studied were added, as well as those of the species Zarafasaura oceanis Vincent, Bardet, Pereda-Suberbiola, Bouya, Amaghzaz, and Meslouh, 2010, from the upper Maastrichtian of Morocco. This data set was chosen because of the high percentage of postcranial characters versus cranial characters, which allows the inclusion of the very informative postcranial aristonectine SGO.PV.260 (Otero et al., 2012). A composite data row of the SGO.PV.957 and SGO.PV.260 (holotype and referred specimen of $A r$. quiriquinensis) was used to add completeness to the latter species. The analysis was performed using TNT version 1.1 (Goloboff et al., 2003) with Traditional Search (Wagner algorithm, 1,000 replicates, TBR with 100 trees to save per replication, implied weighting off). The data set is included in the Supplementary Data 1. Chronostratigraphic formal units used throughout the text follow the International Stratigraphic Chart (Cohen et al., 2013).

\section{SYSTEMATIC PALEONTOLOGY}

SAUROPTERYGIA Owen, 1860

PLESIOSAURIA de Blainville, 1835

ELASMOSAURIDAE Cope, 1869

ARISTONECTINAE O'Keefe and Street, 2009 (sensu Otero et al., 2012)

ALEXANDRONECTES gen. nov.

Type Species-Alexandronectes zealandiensis sp. nov., by monotypy.

Derivation of Name-Genus name after Alexander McKay, who reportedly found both portions of the skull. McKay was the premiere 19th-century collector of pre-Quaternary vertebrate fossils in New Zealand (Bishop, 2008).

Diagnosis-As for the single known species, below.

ALEXANDRONECTES ZEALANDIENSIS gen et sp. nov. (Figs. 2-5) 

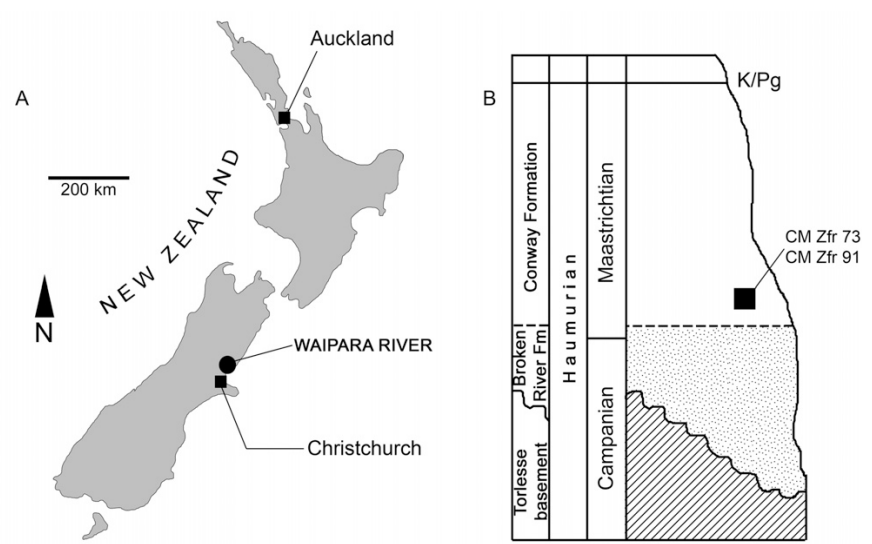

FIGURE 1. A, map of the locality where the studied material was collected; B, stratigraphic section indicating the position of the studied material.

Holotype-A posterior portion of a single skull, preserved in two parts under the catalogue numbers CM Zfr 73 (left portion) and CM Zfr 91 (right portion). New Zealand Fossil Record File number M34/f1073.

Derivation of Name-After Zealandia, the ancient New Zealand continental fragment that broke away from Gondwana during the Late Cretaceous.

Locality, Horizon, and Age-Waipara River, north of Christchurch, New Zealand. Lower levels of the Conway Formation, middle of the local Upper Haumurian Stage, early Maastrichtian. The locality is probably in the lower (or upstream) part of the section of the Conway Formation (approximate location: S $43^{\circ} 03^{\prime} 24^{\prime \prime}$, E $172^{\circ} 34^{\prime} 52^{\prime \prime}$ ).

Diagnosis-Elasmosaurid aristonectine (i.e., Ar. parvidens, Ar. quiriquinensis, K. katiki, and TTU P 9219) with the following unique combination of characters: adult length and width of the skull comparatively smaller than K. katiki, Ar. parvidens, and Ar. quiriquinensis (TTU P 9219 is a juvenile); estimated skull height greater than those of Aristonectes spp. but smaller than that of K. katiki; mandibular glenoid cavity rounded in $\mathrm{Al}$. zealandiensis, with complete exposure of the quadrate in lingual (internal) view, being similar to the lingual exposure on $\mathrm{K}$. katiki but the latter possessing an anteriorly deeper glenoid. Alexandronectes zealandiensis also differs from Ar. quiriquinensis in having an anteriorly deep glenoid, with narrowed exposure of the quadrate in lingual view, due to the lingual extension of the surangular. The dorsal processes of the squamosal arch of $A l$. zealandiensis extended posterolaterally from the midline to produce an A-shaped embayment as in K. katiki (this condition does not occur in Ar. quiriquinensis) but having dorsal branches thicker than those of K. katiki; paroccipital processes shorter and stockier than any other known aristonectine skull, with dorsoventrally expanded and axially compressed distal end, similar to those of Libonectes morgani, and differing from the very long and thin paroccipital processes of Ar. quiriquinensis and TTU P 9219 (the condition remains unknown in K. katiki); distal end of both paroccipital processes having a concave dorsal facet and a convex ventral facet unique among aristonectines preserving this portion; exoccipitals meeting in the ventral midline of the foramen magnum, differing from Ar. quiriquinensis where they do not meet each other in the ventral surface of the foramen.

Remarks-New synapomorphies of the Aristonectinae include the presence of a large plate-like expansion of the pterygoids extending posteriorly beyond the occipital condyle observed in Al. zealandiensis, Ar. quiriquinensis, and probably $K$. katiki, based on the distance between the occipital condyle and the mandibular articulation (not preserved in Ar. parvidens), and differing from the posteriorly unexpanded pterygoid ramus present in more basal elasmosaurids such as Libonectes morgani, Callawayasaurus colombiensis, and Styxosaurus snowii. In addition, the studied specimen lacks a posterior pterygoid symphysis, a condition also observed in the holotype of Ar. quiriquinensis and TTU P 9219 (not preserved in Ar. parvidens and K. katiki). The common presence of these morphologic features in three different aristonectines suggests that it is a potential synapomorphic character. Finally, a third potentially synapomorphic feature is the presence of a large adductor chamber in the squamosal that is partially covered by a roof of the same bone at the posterior end of the temporal fenestra, which is present in the specimen under study here and in Ar. quiriquinensis (not preserved in Ar. parvidens and $K$. katiki).

\section{DESCRIPTION}

Preservation and Ontogenetic Stage-The studied material shows the outlines of most of the cranial sutures, with the exception of those of the exoccipital-opistothics and mandible sutures. This could be a consequence of preparation or of erosion, since some sutures are exposed due to the loss of the thinner bones (e.g., the suture between the basioccipital and the basisphenoid). Abrasion does not appear to have been the cause of such damage, because the loss of bones is selective of thin structures, whereas the more massive portions show minor or no damage. Additionally, disarticulation affected the specimen, because the skull was found isolated and separated in two portions. Loss of other delicate bone portions seems to have occurred in the braincase, where the fenestra ovalis is visible. All elements of the skull appear well-ossified, and even the delicate parts such the distal end of the paroccipital processes are well defined. All of these observations support an adult ontogenetic stage for the specimen.

Exoccipital-Opisthotic-Both elements (Fig. 2A, B) are well preserved and fused as in other plesiosaurs (Brown, 1981), leaving only the jugular foramen between them. The exoccipitalopisthotic displays a small dorsoventral height compared to that in other elasmosaurids such L. morgani (see Carpenter, 1997: fig. 5). Even considering the dorsoventral crushing of the studied specimen, the exoccipital-opisthotics appear to be strongly inclined rostrally, similar to the condition observed in Ar. quiriquinensis and TTU P 9219, and more inclined than in non-aristonectine elasmosaurids (e.g., L. morgani, see Carpenter, 1997: fig. 5). In lateral view, the left exoccipital-opisthotic displays two foramina placed together within an axially elongated depression (Fig. 2A-C). The larger and anterior foramen is identified as the jugular (adult remainder of the developmental metotic fissure) and indicates the exoccipital-opisthotic boundary. The jugular foramen allows the exit from the braincase of cranial nerves IX $+\mathrm{X}$ together with the posterior branch of the jugular vein (Goodrich, 1930). The posterior and smaller foramen is likely for cranial nerve XII. Comparatively, these foramina are much closer together than those observed in the non-aristonectine specimen CM Zfr 115 referred to M. haasti (Hiller et al., 2005) and in T. keyesi (JPO'G pers. obs., 2014). The exoccipitals meet each other ventrally, forming the ventral part of the foramen magnum, excluding the participation of the basioccipital from the ventral surface of the foramen magnum (Fig. 3A, B).

Both paroccipital processes are preserved. The left one is preserved in anatomical position attached to the squamosal, and shows a near $45^{\circ}$ diagonal dorsoventral orientation. The distal end of each paroccipital process is dorsoventrally expanded and has a blade-like shape divided into convex ventral and concave dorsal facets (Figs. 2D, 4E, F). Based on $\mathrm{CM} \mathrm{Zfr} \mathrm{73,} \mathrm{the} \mathrm{distal} \mathrm{contact} \mathrm{of} \mathrm{these} \mathrm{processes} \mathrm{seems} \mathrm{to}$ 

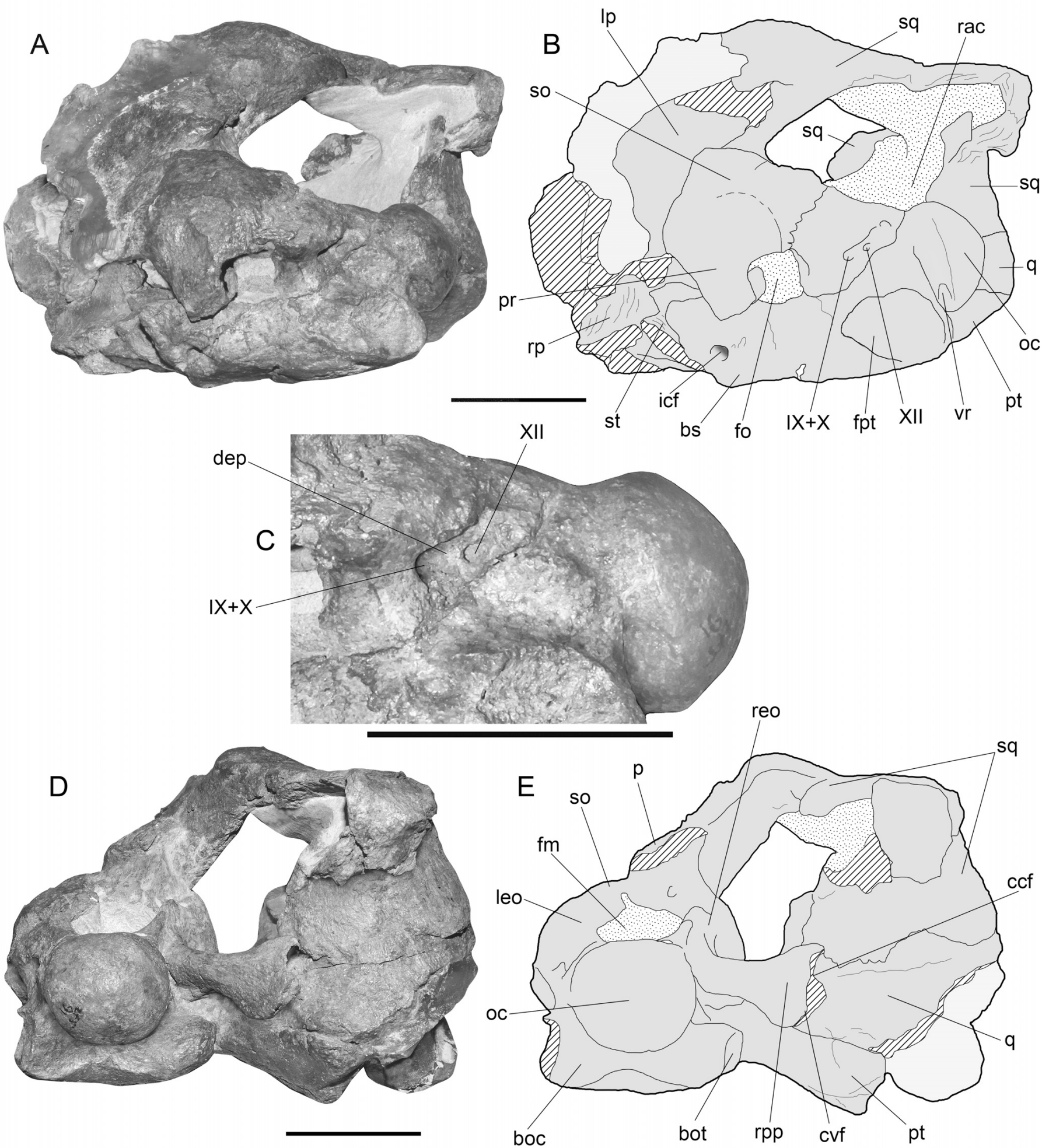

FIGURE 2. Alexandronectes zealandiensis gen. et sp. nov. CM Zfr 91. A, left lateral view of the skull; $\mathbf{B}$, interpretive drawing; $\mathbf{C}$, close-up of the lateral (external) side of the left exoccipital-opistothic showing the large foramen for the cranial nerves IX $+\mathrm{X}$ and a smaller foramen for the nerve XII; $\mathbf{D}$, posterior view of the skull; E, interpretative drawing. Scale bar equals $50 \mathrm{~mm}$ in all cases. For anatomical abbreviations see text.

occur exclusively in a notch in the squamosals, although the presence of two distinctive facets (a concave dorsal and a convex ventral) suggests the participation of a second element, either the quadrate or the pterygoid. The right paroccipital process is crushed along with the right side of the skull and has been brought into contact with the posterior process of the right pterygoid, and is preserved in a near horizontal position. The undeformed preservation of the left paroccipital process together with its length indicate that the distal ends of the paroccipital processes extend ventrally beyond 

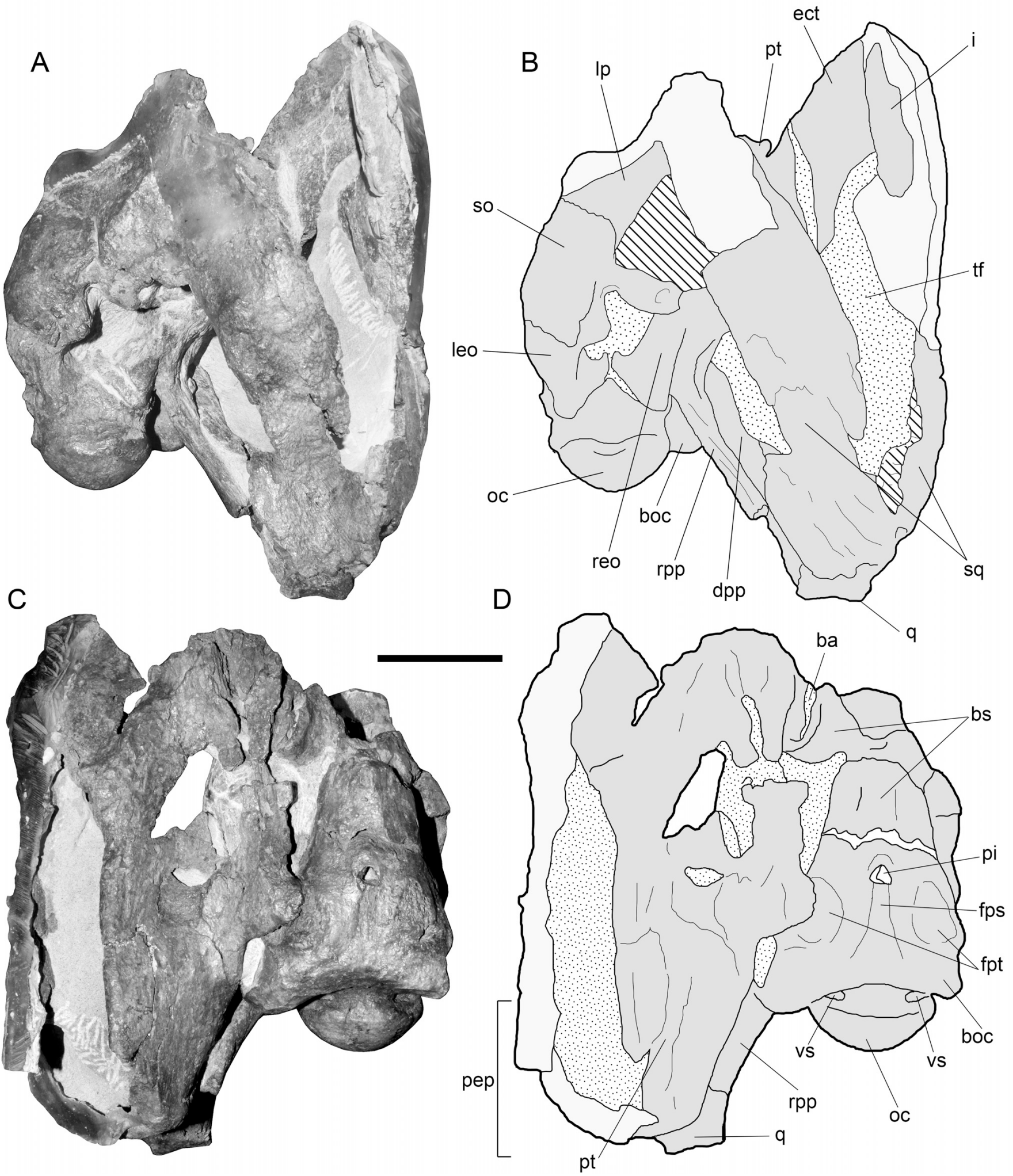

FIGURE 3. Alexandronectes zealandiensis gen. et sp. nov. CM Zfr 91. A, dorsal view of the skull; $\mathbf{B}$, interpretive drawing of the previous; $\mathbf{C}$, ventral view of the skull; $\mathbf{D}$, interpretive drawing. Scale bar equals $50 \mathrm{~mm}$. For anatomical abbreviations see text.

the level of the occipital condyle. The shaft of the paroccipital process is proximally circular, whereas the distal portion is elliptical, dorsoventrally expanded, and craniocaudally compressed.
Supraoccipital-This element encloses the upper part of the braincase and extends ventrolaterally. The suture with the prootic is partially visible but shows a high degree of fusion, consistent with the adult ontogenetic stage of the specimen, whereas 

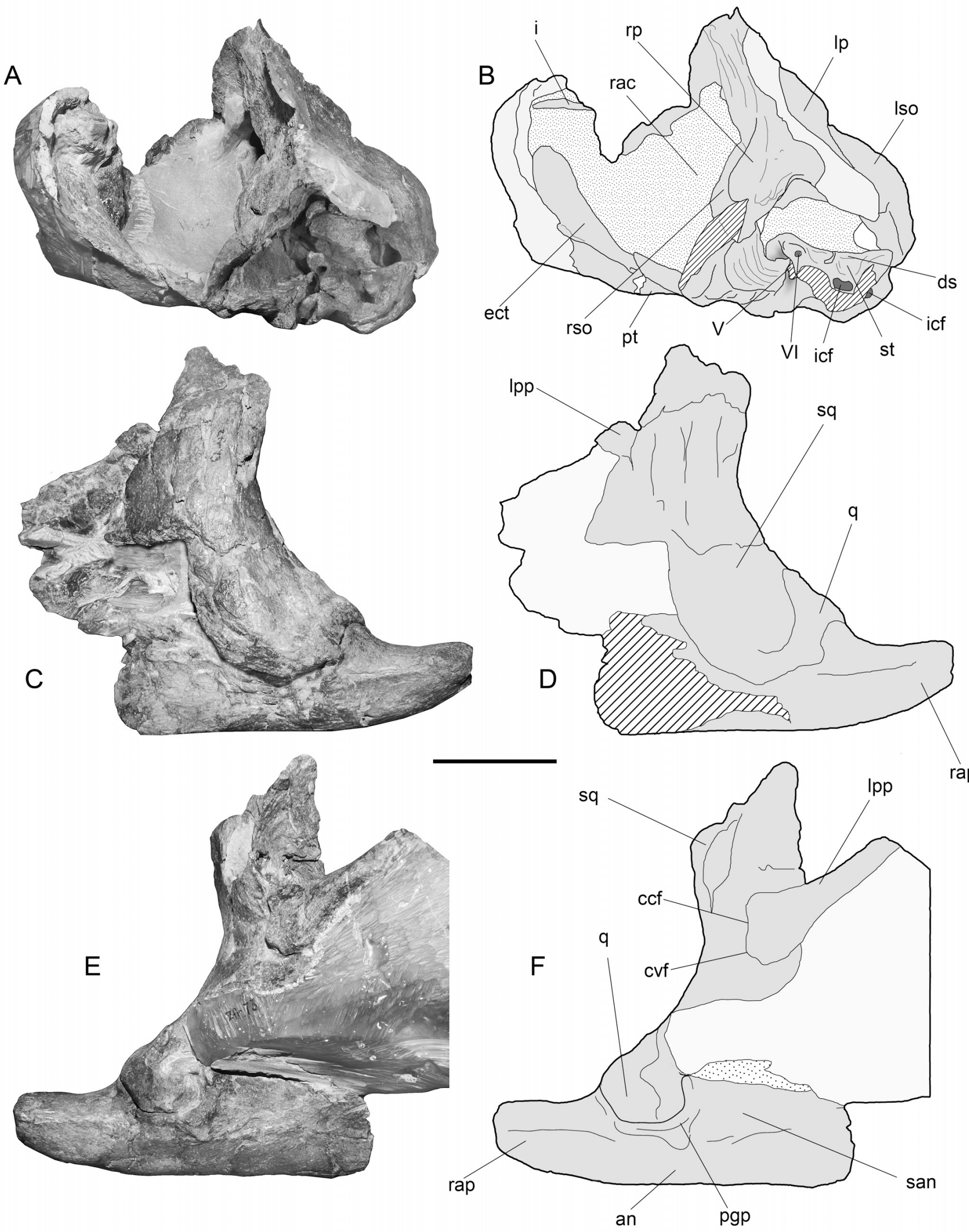

rap

FIGURE 4. Alexandronectes zealandiensis gen. et sp. nov. CM Zfr 91. A, anterior view of the braincase; $\mathbf{B}$, interpretive drawing of the previous. CM Zfr 73; C, left lateral view of the left posterior portion of the skull and left mandible; $\mathbf{D}$, interpretive drawing; $\mathbf{E}$, internal view; $\mathbf{F}$, interpretive drawing. Scale bar equals $50 \mathrm{~mm}$. For anatomical abbreviations see text. 


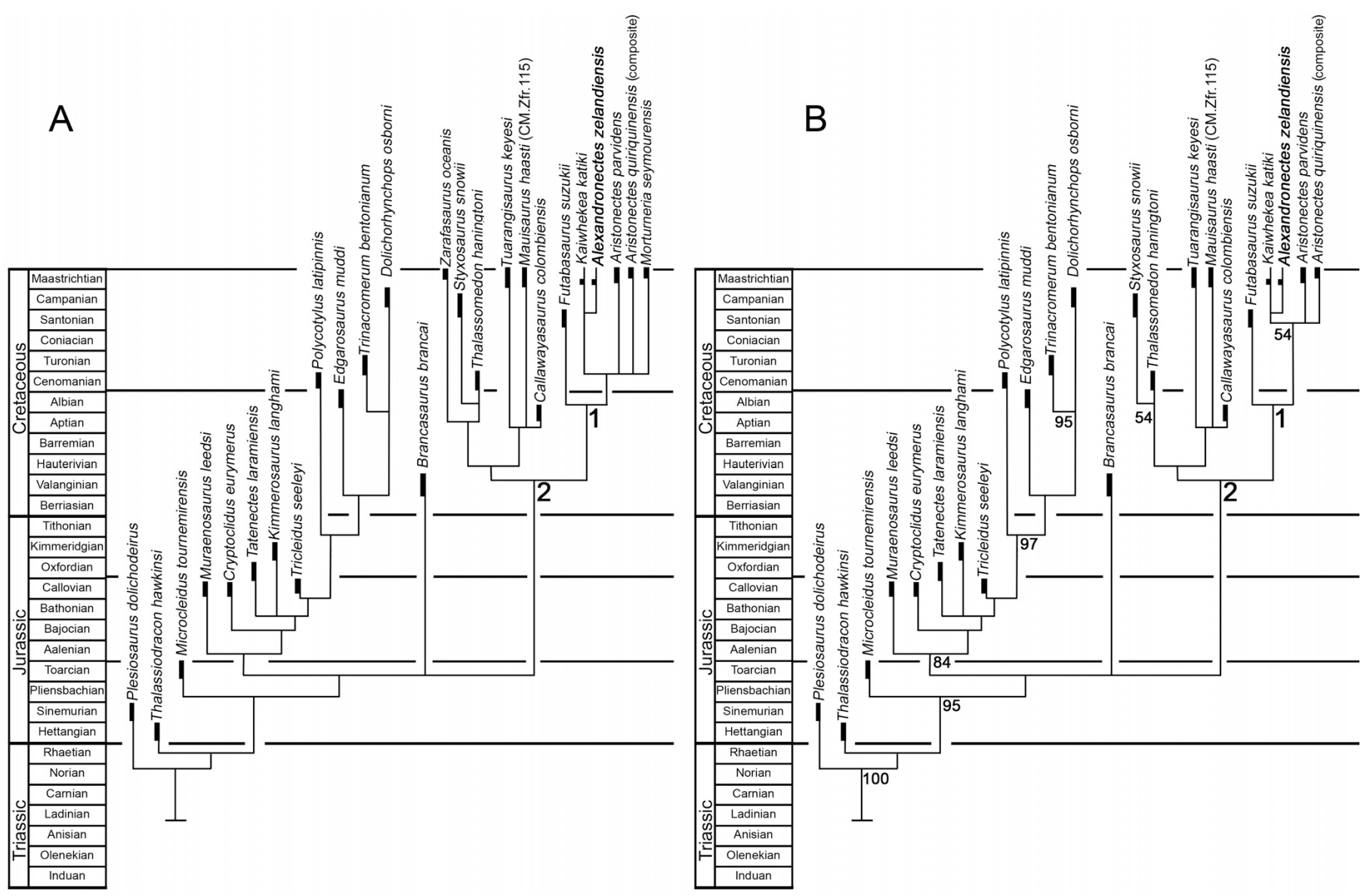

FIGURE 5. A, strict consensus tree (8 MPT, 279 steps, retention index $=0.651$, consistency index $=0.480$ ) of 24 plesiosaur taxa and 91 characters including their stratigraphic occurrences. Hypothesis of relationships of Zarafasaura oceanis returned it among non-aristonectine elasmosaurids such as S. snowii and T. haningtoni; $\mathbf{B}$, strict consensus tree (16 MPT, 263 steps, retention index $=0.673$, consistency index $=0.510$ ) of 22 plesiosaur taxa, excluding ' $M$. seymourensis' and $Z$. oceanis, indicating their respective stratigraphic occurrences, as well as the supported phylogenetic position of Alexandronectes zealandiensis gen. et sp. nov. Resampling indexes (bootstrap $=10,000$ replicates) higher than $50 \%$ are indicated under branches. Bold branches represent known biochrons of each taxon. Positions of nodes are not time calibrated. Node 1, Aristonectinae; Node 2, Elasmosauridae.

the suture with the left exoccipital-opisthotic is still visible and has a sigmoidal outline (Fig. 2A, B).

Prootic-The left prootic is the more visible of both (Fig. 2A, B). It is a massive bone with a larger dorsal portion. The prootic has a posterior notch that forms the anterior limit of the fenestra ovalis. It also has a ventrally directed process that contacts with the basisphenoid. The general proportions (i.e., a larger dorsal part compared with the small ventrally directed process) are similar to the condition observed in Brancasaurus (Wegner, 1914: fig. 8) but differ from that recorded for Dolichorhynchops (Sato et al., 2011:fig 5). It is likely that part of its posterior portion, or an ascending process of the pterygoids, was lost, because the fenestra ovalis is visible in left lateral view, whereas in other elasmosaurid braincases such as Libonectes the fenestra is usually closed (Carpenter, 1997:fig. 5C) or horizontally oriented as in polycotylids (Sato et al., 2011).

Squamosals-Portions of both squamosals are preserved. In $\mathrm{CM}$ Zfr 73 the left squamosal is partially crushed to the right side, whereas CM Zfr 91 has the right squamosal dorsoventrally crushed (Fig. 2A, B). The dorsal portion of the left squamosal is eroded, revealing the left adductor chamber. There is a semicylindrical cavity along the interior surface of the squamosal, posteriorly bounded by the paroccipital process. In occipital view (Fig. 2D, E), the squamosal is a thick and massive element that is dorsally broader than the quadrate and the glenoid of the mandible, in contrast to the squamosals being narrower than the glenoid as observed in some non-aristonectine elasmosaurids (Welles, 1952;figs. 6, 9; 1962:fig. 4). The mid-portion of the right squamosal is dorsoventrally collapsed, although the dorsal end is three-dimensionally preserved. The latter is the thickest portion of the squamosal arch and is in contact with a fragment of the right parietal. In dorsal view, the arch formed by both squamosals is anteriorly shifted over the braincase, in an ' $\mathrm{A}$ '-shaped outline.

Quadrate-The better preserved quadrate is the left, whereas the right one is crushed and incomplete. In dorsal view, the articular facet of the quadrate is slightly broader than the mandibular glenoid, and its articular surface is diagonally oriented with respect to the craniocaudal axis. The dorsal surface of the quadrate has a broad contact with the pterygoids. The medial outline of the quadrate is posteriorly deeper (Fig. 4E, F), in contrast to the condition in K. katiki and Ar. quiriquinensis, where this is anteriorly deeper (see below for further discussion).

Pterygoids-Only the right pterygoid is preserved. The element differs from most other elasmosaurids in possessing a large horizontal projection of the pterygoid plate lateral to the posterior interpterygoid vacuity, extending posteriorly with respect to the occipital condyle. The quadrate ramus of the pterygoid is also thickened and cannot be distinguished from the rest of the plate. There is no posterior pterygoid symphysis (Fig. 3C, D). 
The posterior part of the pterygoid plate has a slight ventral concavity, similar to the condition in Ar. quiriquinensis and to most elasmosaurids and polycotylids. Its right lateral edge is slightly thicker than the rest of the bone. Its medial portion is damaged, making difficult to evaluate the contacts with other elements, such as the parasphenoid. Despite this, the contact with the basioccipital is partially visible and both elements share an articular facet with a rounded outline that is visible on the basioccipital sides. A dorsal process of the pterygoid can be observed in occipital view, being covered by the paroccipital process.

Basioccipital-Specimen CM Zfr 91 preserves the basioccipital in anatomical position (Fig. 3C, D). Together the basioccipital and basisphenoid have a triangular outline in ventral view (Fig. 3C, D) and are separated by a deep suture. The basioccipital is massive and has short, laterally projecting basioccipital tubers for articulation with the pterygoids. The occipital condyle is large, hemispherical, and completely encircled by a neck. In posterior view the condyle is broader than half of the total width of the basioccipital body (Fig. 3C, D). There is no participation of the exoccipital-opistothics in the formation of the occipital condyle as in other elasmosaurids and polycotylids (Druckenmiller, 2002; Sato et al., 2011) but unlike Cryptoclidus where the exoccipital pedicels participate in the formation of the occipital condyle (Brown, 1981:fig. 2). Two bilateral rectangular recesses are present on the ventral surface of the condyle neck (Figs. 2A, $\mathrm{B}, 3 \mathrm{C}, \mathrm{D})$. In lateral view, the suture between the basioccipital and the exoccipital-opisthotics is diagonal and reaches an angle of near $45^{\circ}$ with respect to the horizontal plane, a condition that may be exaggerated due to deformation of the skull. In ventral view, the basioccipital has a nearly trapezoidal outline (Fig. 3C, D). The midline of the ventral surface bears a central shallow scar that could indicate the articulation of a long and thin posterior part of the parasphenoid, which is not preserved. This scar ends in a small foramen surrounded by a shallow bony wall (Fig. 3C, D). A medial foramen near the low suture between the basisphenoid and basioccipital was regarded as an informative character in recent phylogenetic analyses (Ketchum and Benson, 2010: Character 70). A similar foramen is indeed present in other plesiosaurs (i.e., juvenile Cryptoclidus, Andrews 1910:pl. 9, fig. 5; holotype of Hauffiosaurus tomistomimus, in Benson et al. 2011: fig. 6C), indicating that it could be present in both juvenile and adult specimens. The foramen observed in Al. zealandiensis and Hauffiosaurus tomistomimus could represent the basicranial fontanelle, a nonossified remnant of the embryonic fenestra basicranialis in the area of the basisphenoid-basioccipital contact, which is present in some tetrapods (Conrad [2004] and references therein).

Basisphenoid-This bone is as axially long as the basioccipital and has a triangular ventral outline. The suture with the basioccipital appears as a deep groove, probably due to erosional bone loss. In lateral view, the foramen for the left carotid is visible. The anterior portion of the basisphenoid is damaged but preserved on the right side, including the basipterygoid process that articulates with the pterygoid. This portion is broader than the distal end, having a ' $T$ ' shape in ventral view (Fig. 3C, D). The ventral surface is flattened, with a central scar likely for the now lost parasphenoid (Fig. 3C, D).

Internal Braincase Structures-Visible in anterior view are the dorsum sellae, the sella turcica, the section of the canal for the right trigeminal nerve (V), the foramen of the abducens nerve (VI), and the opening of the internal carotid foramina (which seem to open as a single foramen in the floor of the sella turcica). Additionally, the entrance of the left internal carotid foramen is visible in the left side of the braincase in anterior view (Fig. 4A, B). Part of the right parietal is preserved and shows a partially rugose internal surface. This parietal is partially collapsed, covering part of the right trigeminal canal. The size of the sella turcica relative to the rest of the braincase seems to be similar to most plesiosaurs (Andrews, 1910:fig. 73; Druckenmiller, 2002:fig. 9; O'Keefe, 2001:fig. 1), although there are noticeable differences in the proportions of this structure between the holotype of Ar. quiriquinensis and Al. zealandiensis. The first possesses a remarkably large infundibulum and comparatively thicker scars for the cranial nerves (RAO, pers. obs., 2013).

Mandibles-Only a portion of the left posterior mandibular ramus is preserved, attached to the left posterior portion of the skull (Fig. 4C-F). This has a short retroarticular process recurved medially as well as dorsally, whereas the glenoid is mostly covered by the collapsed left squamosal and quadrate. The quadrate/articular is diagonally disposed with respect to the craniocaudal axis (i.e., the medial margin of the glenoid is posterior to its respective lateral margin). In lingual view, the surangular bears a preglenoid process that vertically rises anterior to the glenoid. The quadrate is completely exposed in lingual view (contrary to the condition observed in Ar. quiriquinensis; see below). In the same view, the mandibular glenoid is quite rounded and has a slight posterior excavation.

Relative Size of Aristonectine Skulls-Specimens CM Zfr 73 and 91, the holotype of $K$. katiki, as well as the holotype of $A r$. quiriquinensis are all adult specimens based on the observed fusion between cranial elements and the general lack of sutures on each skull. K. katiki and Ar. quiriquinensis have similar rostrocaudal length, the first being slightly smaller. On the other hand, Al. zealandiensis is even smaller in size compared with these two taxa. Its width at the occipital condyle level is near two thirds that of Ar. quiriquinensis. Although the craniocaudal length of $A l$. zealandiensis cannot be established due to its incompleteness, the skull is indeed smaller than that of $K$. katiki based on the shorter retroarticular processes as well as the comparatively smaller size of the mandibular portions preserved in Al. zealandiensis.

\section{DISCUSSION}

\section{Phylogenetic Analysis}

A first phylogenetic analysis included Zarafasaura oceanis, which was added to the data set because in its skull the pterygoids extend posteriorly beyond the occipital condyle as occurs in Al. zealandiensis, Ar. quiriquinensis, and likely in K. katiki, making it relevant for testing the phylogenetic relationships among these taxa. Eight most parsimonious trees (MPTs) were obtained, with a length of 279 steps, retention index $=0.651$, and consistency index $=0.480$. The strict consensus tree returned $Z$. oceanis among non-aristonectine elasmosaurids such as Styxosaurus snowii (Williston, 1890) and Thalassomedon haningtoni Welles, 1943, whereas aristonectines were returned as a monophyletic group with an internal polytomy. Alexandronectes zealandiensis and $K$. katiki were obtained as sister taxa. Subsequent phylogenetic analysis used the IterPcr script (Pol and Escapa, 2009 ) to identify ' $M$. seymourensis' and $Z$. oceanis as the most unstable taxa, which were subsequently pruned. The new data set was reanalyzed, returning 12 MPTs with a length of 263 steps, retention index $=0.673$, and consistency index $=0.510$. The strict consensus tree shows Al. zealandiensis within the Aristonectinae as a sister taxon of K. katiki but separated with respect to Aristonectes spp. Bootstrap analyses (Poisson independent reweighting, Ratchet search) were performed to test tree stability $(10,000$ replicates). Values over 50\% support the clade (Aristonectes spp. $+K$. katiki + Al. zealandiensis). Because the scored characters of the studied specimen represent only $20 \%$ of the complete data set, support for the analysis is weak, although it results in Al. zealandiensis falling within the Aristonectinae. The clade including $K$. katiki and $A l$. zealandiensis is supported by a synapomorphic high skull profile (Ch. 85, state 1). A strict consensus 

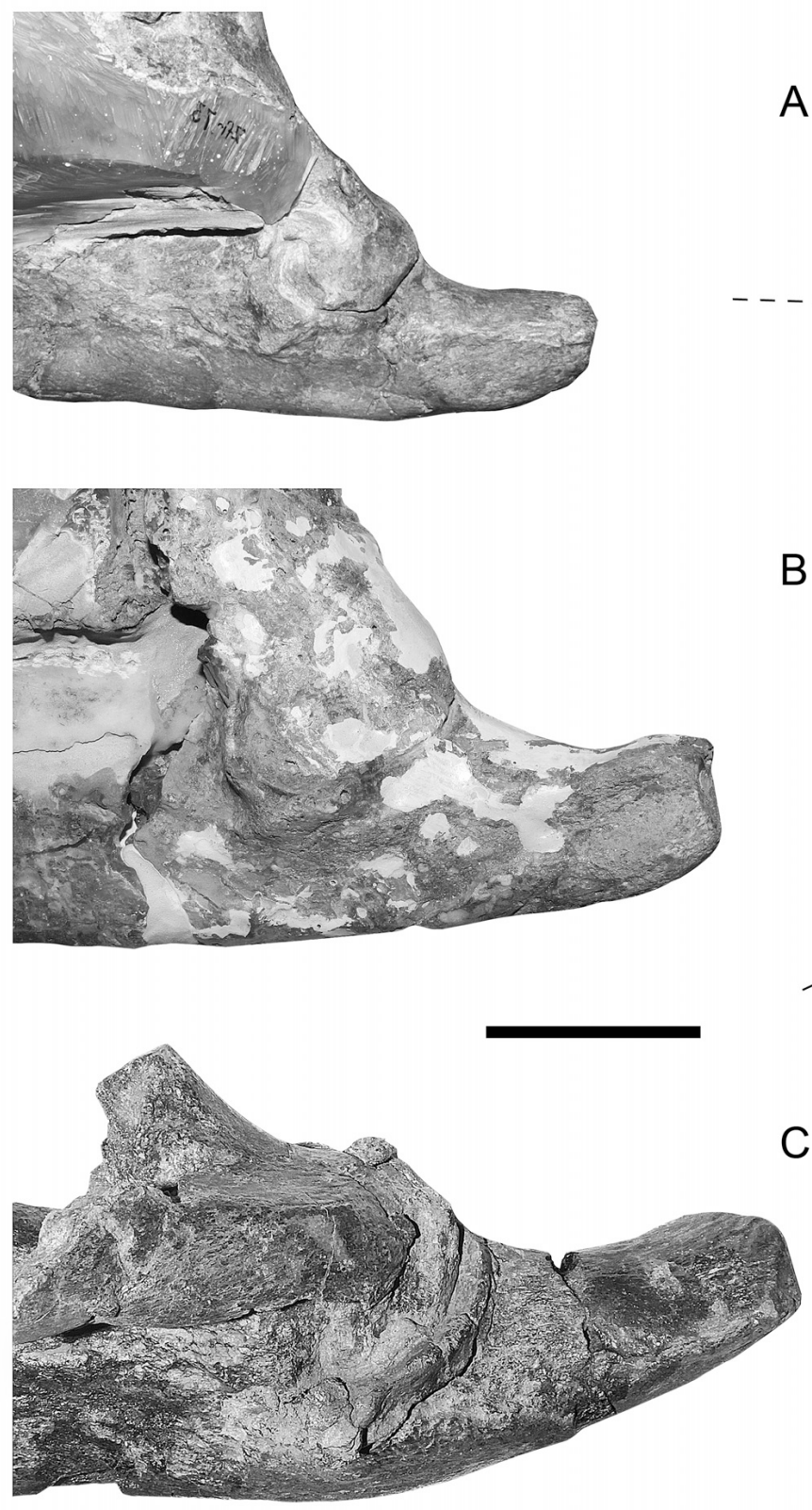

C
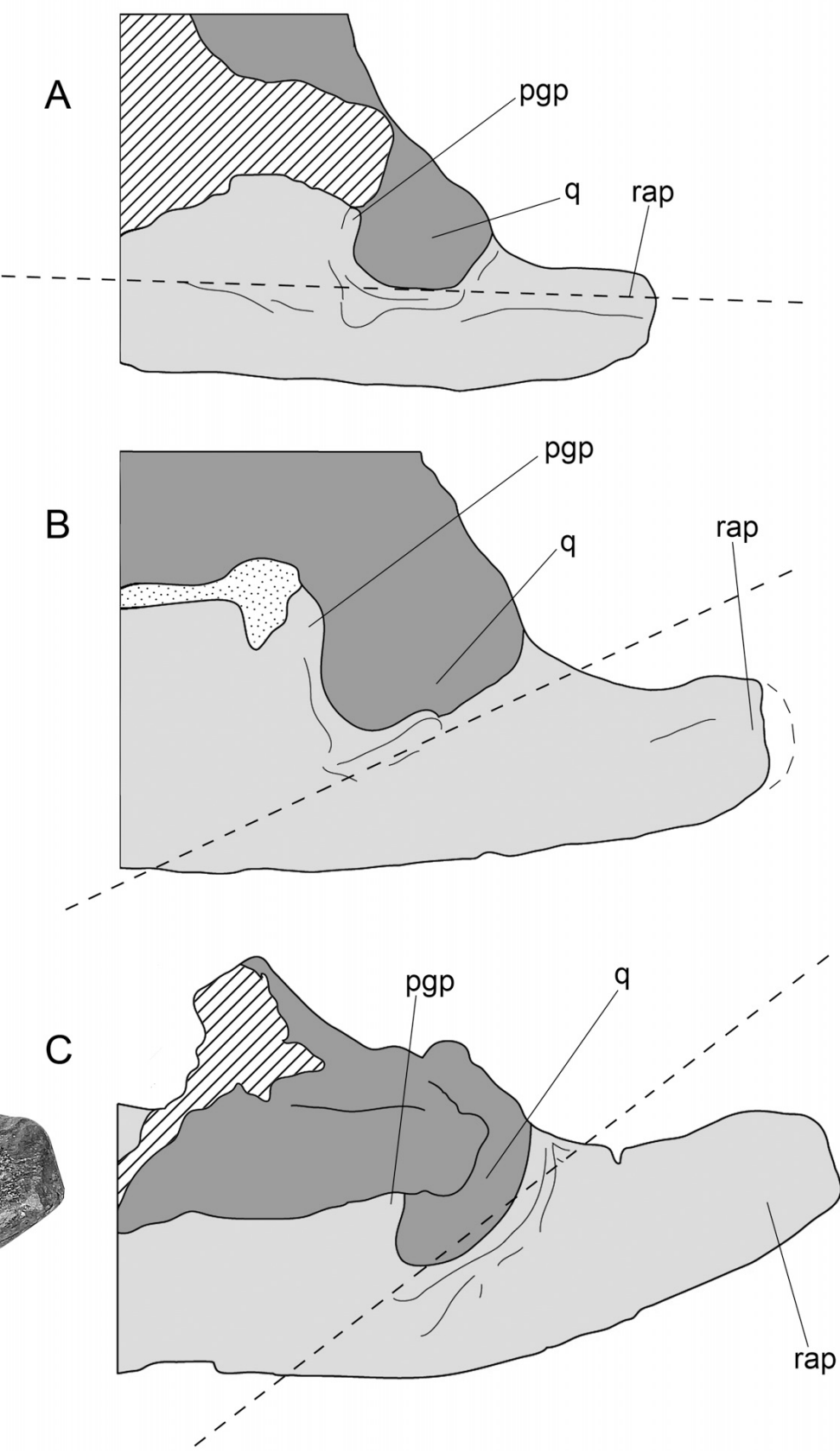

FIGURE 6. Comparison of the mandibular glenoids among aristonectines. A, Alexandronectes zealandiensis gen. et sp. nov. (CM Zfr 73, holotype), lingual (internal) view, mirrored for better comparison; B, Kaiwhekea katiki (OU 12649, holotype), lingual view; C, Aristonectes quiriquinensis (SGO. PV.957, holotype), lingual view. Dashed lines indicate the inclination of the largest flat surface of the glenoid fossa. Scale bar equals $50 \mathrm{~mm}$. For anatomical abbreviations see text.

tree and the bootstrap result were integrated with the stratigraphic occurrence of each taxon (Fig. 5).

\section{Potentially New Synapomorphies of the Aristonectinae}

Alexandronectes was compared with other contemporary taxa from the Weddellian Biogeographic Province, showing new possible synapomorphies of Aristonectinae, based on the comparative study of the known skulls. First, the plate-like extension of the pterygoids far posterior to the occipital condyle is certainly present in Aristonectes quiriquinensis and the same condition is likely to occur in K. katiki. The latter interpretation is based on the relative position of the occipital condyle with respect to the mandibular glenoid, which are comparatively more separated than in Al. zealandiensis and similar to Ar. quiriquinensis. A skull extending far posterior to the occipital condyle is also present in Z. oceanis from the upper Maastrichtian of Morocco. In ventral view of the holotype of this species, as well as in a second specimen described by Lomax and Wahl (2013), it can be seen that the posterior projection is mostly supported by an extension of palatal elements, likely the pterygoids (although these are not interpreted in the description by Lomax and Wahl (2013). Even 
if this is the case, the thin posterior process of each putative pterygoid is noticeably different from the thick and flat posterior pterygoidal extension observed in Al. zealandiensis and Ar. quiriquinensis. In addition, the absence of the posterior pterygoid symphysis observed in TTU P 9219 and in the holotype of $A r$. quiriquinensis (unknown in Ar. parvidens and $K$. katiki) is another unusual feature among elasmosaurids (O'Keefe, 2001). Together with this, the presence of exoccipital-opisthotics that are highly inclined rostrally and the presence of a diagonal suture plane with the basioccipital are features in common with $A r$. quiriquinensis and TTU P 9219, although exaggeration due to deformation is possible. Another potentially relevant character is the presence of two rectangular recesses symmetrically placed in the ventral part of the neck of the occipital condyle of Al. zealandiensis. A similar feature is observed in the right preserved portion of the occipital condyle of TTU P 9219 (FRO, pers. obs., 2013), but it is difficult to evaluate this character in Ar. quiriquinensis and $K$. katiki because of the preservation of these specimens.

\section{Diagnostic Value of the Mandibular Glenoid and Retroarticular Process among Aristonectines}

Comparison of the mandibular glenoid of Al. zealandiensis with known aristonectine skulls (Fig. 6) shows that the former possesses a comparatively rounded glenoid, whereas in $K$. katiki the glenoid deepens anteriorly, has a high preglenoid process at the lingual end of the surangular, and its medial outline looks subtriangular instead of rounded. In addition, the retroarticular process of Al. zealandiensis is comparatively straight, and the distal end of this process in $K$. katiki bears a slight dorsal curvature. In contrast, the glenoid of Ar. quiriquinensis shows evident differences. This has a marked anterior depth and the whole glenoid is horizontally rotated, leaving the medial exposure of the quadrate in an anterior position with respect to its external outline. Thus, the articulation has a diagonal orientation in dorsal view. A similar condition is observed in $K$. katiki and Al. zealandiensis, but in these taxa it is less accentuated. In addition, the retroarticular process of $A$. quiriquinensis is even more recurved than that of Al. zealandiensis and K. katiki.

\section{Diagnostic Value of the Paroccipital Processes among Aristonectines}

Comparison of the skulls of Weddellian aristonectines has revealed great variability in the morphology of the paroccipital processes. Each paroccipital process in Al. zealandiensis is distally expanded with an axially compressed shaft. A distally expanded paroccipital process end is recorded in L. morgani (Carpenter, 1999:fig. 9B) and C. colombiensis (Carpenter, 1999: fig. 13A), although the shaft of the latter taxa is more gracile and the distal expansion is less developed than in Al. zealandiensis. Among aristonectines where this element is known (i.e., Al. zealandiensis, TTU P 9219, and A. quiriquinensis), the paroccipital processes of $A l$. zealandiensis are distinctively short and blunt, whereas the processes are long and slender in the late Maastrichtian taxa TTU P 9219 and Ar. quiriquinensis. In addition, the paroccipital processes of TTU P 9219 and Ar. quiriquinensis differ. In TTU P 9219 the process is comparatively shorter and straight, whereas the process of Ar. quiriquinensis has a much larger, thin, and medially curved shaft. Conversely, in both taxa the attachment of the paroccipital process contacts the squamosal through its distal end as in most elasmosaurids. Because of a taphonomic artifact, the paroccipital processes of Ar. quiriquinensis are both distally attached beside each squamosal, including about half of the shaft in each contact (Fig. 7A-C). In $A l$. zealandiensis, despite the articulation of the paroccipital process only involving its distal end, this could have an eventual contact with other elements besides the squamosal, because of the
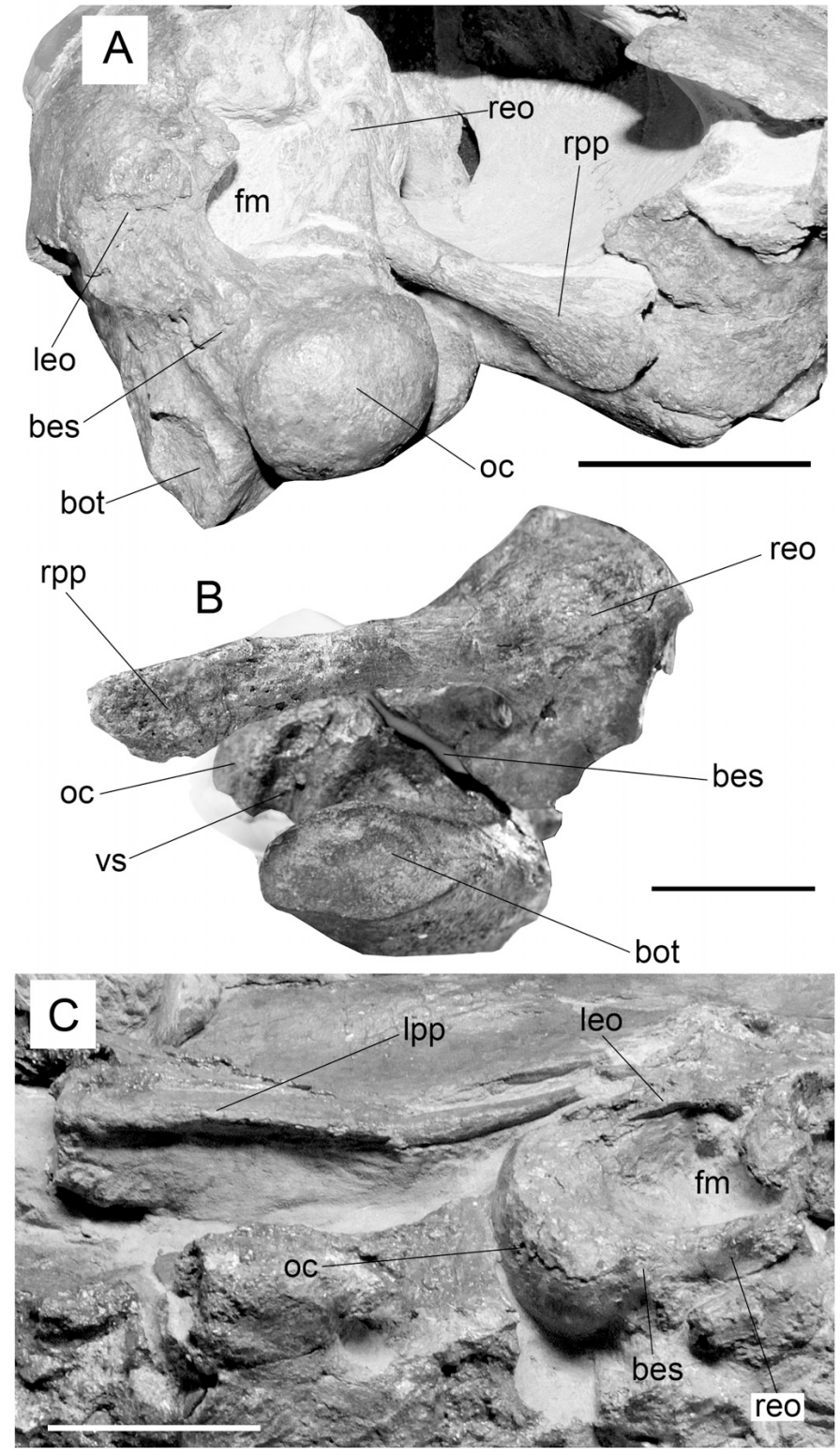

FIGURE 7. Comparison of the posterior braincase and paroccipital processes of aristonectines. A, posterior braincase of Alexandronectes zealandiensis gen. et sp. nov. (CM Zfr 91) in left posterodorsal view; $\mathbf{B}$, posterior braincase of the holotype of Morturneria seymourensis (TTU P 9219) in right lateral view; C, posterior braincase of the holotype of Aristonectes quiriquinensis (SGO.PV.957) in right dorsolateral view. Images are not to scale but resized for better anatomical comparison. Scale bars equals $50 \mathrm{~mm}$ in A and B, $20 \mathrm{~mm}$ in C. For anatomical abbreviations see text.

presence of two distal facets. A multiple articulation of this element is known in other elasmosaurids, such as L. morgani, where the distal end of the paroccipital articulates with the pterygoid, the squamosal, and the quadrate (FRO, pers. obs., 1998).

\section{Morphological Patterns of the Skull in Aristonectines}

The general aspect of the skull of Al. zealandiensis is more similar to those of non-aristonectine elasmosaurids than to the late Maastrichtian aristonectines from Antarctica and Chile. Unfortunately, it cannot be compared with older potential aristonectines such as Futabasaurus suzukii Sato, Hasegawa and Manabe (2006) 
from the Santonian of Japan, because the same portions of the skull are not preserved. As mentioned by Cruickshank and Fordyce (2002), the skull of Kaiwhekea suffered severe lateral compression, probably exaggerating the high profile of the sagittal crest. However, the length of the temporal fenestra and the retracted position of the mandibular glenoid still suggest the presence of increased mass of the jaw adductor muscles (Araújo and Polcyn, 2013). In the case of $\mathrm{Al}$. zealandiensis, the posterior extension of the pterygoids is consistent with an enlargement of the temporal fossa, although the dorsal 'A'-shaped squamosal arch causes the adductor muscles (i.e., musculus adductor mandibulae externus medialis and musculus adductor mandibulae externus profundus; Araújo and Polcyn, 2013) to be diagonally disposed between the sagittal crest and the internal surface of the squamosal (i.e., adductor chamber). The posterior extension of the pterygoids and the enlargement of the temporal fossa are indeed present in Ar. quiriquinensis, where the condition reaches an extreme modification and a probable reduction of the height of the sagittal crest associated with the more horizontal disposition of the mandibular musculature. Finally, by comparing the adult size of the evaluated taxa (Fig. 8A-G), the posterior skull extension in $K$. katiki appears as an intermediate condition between $\mathrm{Al}$. zealandiensis and the extreme elongation in Ar. quiriquinensis.

\section{Paleobiogeography of the Aristonectinae}

Aristonectines are a group of plesiosaurs generally restricted to the uppermost Cretaceous of the Southern Hemisphere (i.e.,
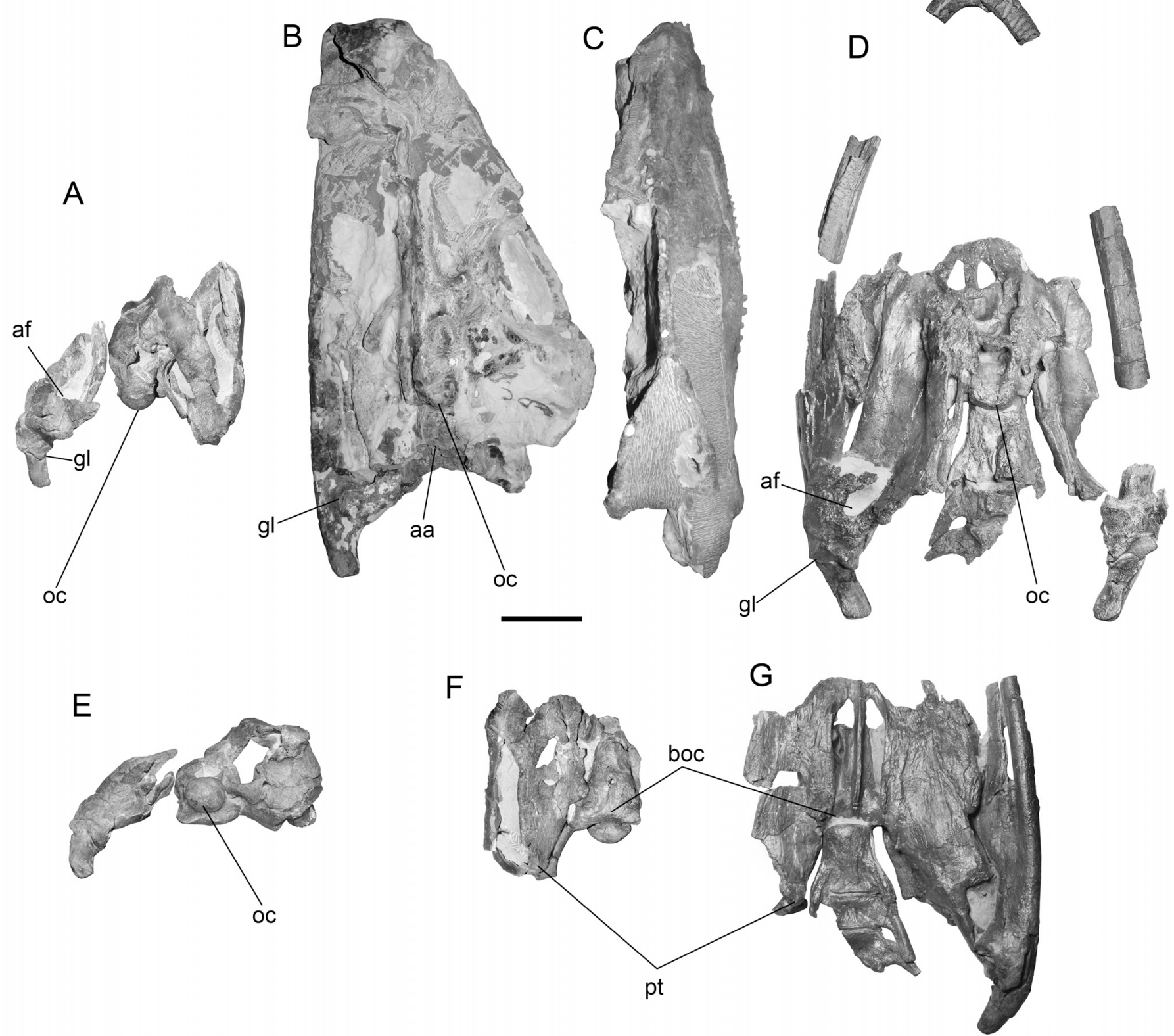

FIGURE 8. Comparison of aristonectine skulls. A, Alexandronectes zealandiensis gen. et sp. nov. (CM Zfr 73 and CM Zfr 91) in dorsal view; B, skull of the holotype of Kaiwhekea katiki (OU 12649) in left lateral view; C, same in dorsal view; D, skull of the holotype of Aristonectes quiriquinensis (SGO.PV.957) in dorsal view; E, Alexandronectes zealandiensis gen. et sp. nov. (CM Zfr 91 and ZM Zfr 73) in posterior (occipital) view; F, same in ventral view; G, skull of the holotype of Aristonectes quiriquinensis (SGO.PV.957) in ventral view. Scale bar equals $100 \mathrm{~mm}$. For anatomical abbreviations see text. 
Antarctica, New Zealand, and southern South America). They have also been reported from the lower Maastrichtian of Angola (Araújo et al., 2015); although none of the referred specimens preserve skull portions, few described cervical centra show typical proportions (vertebral length indices of Welles, 1952) commonly observed among aristonectines. Thus, it is necessary to evaluate more complete material in order to establish the affinities of the specimens referred to aristonectines from the lower Maastrichtian of Angola.

Aristonectines were originally characterized by having skulls with more than 50 maxillary teeth, fewer than 45 cervical vertebrae of reduced length, and cervical neural spines recurved rostrally (Otero et al., 2012). Previous records of this group include indeterminate aristonectines from the upper Campanian of James Ross Island, Antarctica (Otero et al., 2014a), and similar specimens from the lower Maastrichtian of Seymour Island, Antarctica (Fostowicz-Frelik and Gaździcki, 2001); indeterminate aristonectines from the upper Campanian-lower Maastrichtian and upper Maastrichtian of Patagonia (O'Gorman et al., 2013; O'Gorman et al., 2014a) and the endemic species K. katiki from the lower Maastrichtian of New Zealand (Cruickshank and Fordyce, 2002); a juvenile, indeterminate aristonectine from a slightly higher level of the Conway Formation as the specimen described here (O'Gorman et al., 2014b) and widespread upper Maastrichtian records, among them the specimens referred to 'M. seymourensis' Chatterjee and Small (1989) and Aristonectes sp. (O'Gorman et al., 2010, 2013) from Seymour and Vega islands, respectively; Ar. parvidens from Argentinean Patagonia (Cabrera, 1941; Gasparini et al., 2003b) and Ar. quiriquinensis from central Chile (Otero et al., 2014b).

Assigning Al. zealandiensis to the subfamily Aristonectinae adds to the geographic distribution and stratigraphic occurrence of the group. Based on phylogenetic analyses (Otero et al., 2012; Benson and Druckenmiller, 2014; Otero, et al., 2014b), the aristonectine clade within the Elasmosauridae diverged during the Late Cretaceous to include all of the highly modified forms from the Weddellian Biogeographic Province, with the possible inclusion of $F$. suzukii from Japan as a basal form, although this last was recovered as not directly related to the aristonectines by O'Gorman et al. (2015). In any case, the divergence of aristonectines from other elasmosaurids is documented at least as far back as the Santonian-Campanian. The addition of Al. zealandiensis emphasizes the notable elasmosaurid diversity in the lower Maastrichtian of New Zealand and also indicates that aristonectines could include small-sized species.

The Weddellian record of late Maastrichtian aristonectines is the most widespread and richest in number of specimens recovered so far. Records in Antarctica include at least three highly informative specimens that undoubtedly belong to the Aristonectinae: TTU P 9219, referred to M. seymourensis (Chatterjee and Small, 1989) and later to Ar. parvidens (Gasparini, Bardet, et al., 2003); MLP 89-III-3-2, referred to $A r$. aff. parvidens (O'Gorman et al., 2013); and MLP 05-I-1-15, referred to Ar. parvidens (O'Gorman et al., 2010). During the same time span, the record also extends to Argentinean Patagonia, along the ancient Atlantic with scarce but informative specimens (holotype of $A r$. parvidens Cabrera, 1941) and also with postcranial remains referable to the clade (Gasparini, Salgado, and Casadío et al., 2003a, O'Gorman et al., 2013; O'Gorman et al., 2014a). Along the southeastern Pacific, there is a marked dominance of aristonectines over other elasmosaurids. Based on the collections hosted in the Museo Nacional de Historia Natural (Santiago, Chile), the main components of the Maastrichtian marine reptile fauna are aristonectines, with several specimens referable to Ar. quiriquinensis, although several isolated, very large elements suggest the presence of a second, different form or possibly somewhat disparate older individuals (Suazo and Otero, 2014); in addition, a partially articulated skeleton under study (SGO.PV.6505) belongs to a different, smaller taxon, thus indicating the existence of a diversity of aristonectines in this realm during the late Maastrichtian.

\section{CONCLUSIONS}

In its first description, the material CM Zfr 73 and CM Zfr 91 was correctly identified as the remains of a single individual of an indeterminate elasmosaurid, though generic and specific determinations were not possible at that time due to the lack of sufficient comparative material. More recent descriptions of new elasmosaurids from the Weddellian Biogeographic Province now allow realization that this unique specimen represents a new taxon of Upper Cretaceous elasmosaurid from New Zealand. Morphological features of the studied skull allow the recognition of new putative synapomorphies of the Aristonectinae. These are the presence of pterygoids extending far posterior to the occipital condyle forming a plate-like extension and not meeting posterior to the interpterygoid vacuities, as well as the presence of a large adductor chamber inside the squamosal, partially covered by a roof of the same bone at the posterior end of the temporal fenestra. The new taxon described here is relatively morphologically conservative among aristonectines; however, exact cranial proportions cannot be determined due to distortion. The new taxon differs from other Weddellian aristonectines in the possession of a comparatively smaller skull than those of the holotypes of Ar. parvidens, Ar. quiriquinensis, and K. katiki. In addition, in $K$. katiki there is a high sagittal crest, which seems to be much lower in Aristonectes spp. and TTU P 9219, whereas in $A l$. zealandiensis the height of the sagittal crest likely represents an intermediate condition. In addition, the mandibular glenoid of $\mathrm{Al}$. zealandiensis is rounder than that of $K$. katiki, the latter being anteriorly deeper, and also differs from Ar. quiriquinensis; this taxon has a markedly recurved glenoid with a partial covering of the quadrate in lingual view due to an extension of the surangular. Finally, the retroarticular process of Al. zealandiensis is straighter than that of $K$. katiki and differs markedly from the dorsally recurved retroarticular process of Ar. quiriquinensis. The less pronounced posterior extension of the pterygoids, the rounded mandibular glenoid, the straighter retroarticular process, and the smaller adult skull size of $\mathrm{Al}$. zealandiensis suggest that this taxon was less morphologically (and hence functionally) derived than late Maastrichtian taxa such Ar. parvidens and Ar. quiriquinensis.

\section{ACKNOWLEDGMENTS}

RAO was supported by the Antarctic Ring Project (Anillos de Ciencia Antártica ACT-105, Conicyt-Chile) and additional support was provided by the Domeyko II UR-C12/1 grant-Red Paleontológica U-Chile of the Universidad de Chile. JPO'G was supported by projects PIP 0433, PICT 2012-0748, PICTO 20100093, UNLP N 677, UNLP N607. The authors thank P. Scofield and C. Vink (Canterbury Museum, Christchurch, New Zealand) for allowing us to review the elasmosaur material hosted in the Canterbury Museum. P. Druckenmiller (Department of Geology and Geophysics, University of Alaska Fairbanks) and a second anonymous reviewer are thanked for their very valuable comments and observations that improved this article.

\section{LITERATURE CITED}

Andrews, C. W. 1910. A Descriptive Catalogue of the Marine Reptiles of the Oxford Clay, Part I. British Museum (Natural History), London, 205 pp.

Araújo, R., and M. J. Polcyn. 2013. A biomechanical analysis of the skull and adductor chamber muscles in the Late Cretaceous plesiosaur Libonectes. Palaeontologia Electronica 16:1-25.

Araújo, R., M. J. Polcyn, J. Lindgren, L. L. Jacobs, A. S. Schulp, O. Mateus, A. Olímpio Gonçalves, and M.-L. Morais. 2015. New 
aristonectine elasmosaurid plesiosaur specimens from the early Maastrichtian of Angola and comments on paedomorphism in plesiosaurs. Netherlands Journal of Geosciences - Geologie en Mijnbouw 94:93-108.

Benson, R. B. J., and P. S. Druckenmiller. 2014. Faunal turnover of marine tetrapods during the Jurassic-Cretaceous transition. Biological Reviews 89:1-23.

Benson, R. B. J., H. F. Ketchum, L. F. Noè, and M. Gómez-Pérez. 2011. New information on Hauffiosaurus (Reptilia, Plesiosauria) based on a new species from the Alum Shale Member (lower Toarcian: Lower Jurassic) of Yorkshire, UK. Palaeontology 54:547-571.

Bishop, D. G. 2008. The Real McKay: The Remarkable Life of Alexander McKay, Geologist. Otago University Press, Dunedin, New Zealand, $252 \mathrm{pp}$.

Brown, D. S. 1981. The English Late Jurassic Plesiosauroidea (Reptilia) and review of the phylogeny and classification of the Plesiosauria. Bulletin of the British Museum (Natural History), Geology 4: 225-234.

Cabrera, A. 1941. Un Plesiosaurio nuevo del Cretáceo del Chubut. Revista del Museo de La Plata 2:113-130.

Carpenter, K. 1997. Comparative cranial anatomy of two North American Cretaceous plesiosaurs; pp. 191-216 in J. M. Callaway and E. L. Nicholls (eds.), Ancient Marine Reptiles. Academic Press, San Diego, California.

Carpenter, K. 1999. Revision of North American elasmosaurs from the Cretaceous of the Western Interior. Paludicola 2:148-173.

Chatterjee, S., and B. S. Creisler. 1994. Alwalkeria (Theropoda) and Morturneria (Plesiosauria), new names for preoccupied Walkeria Chatterjee, 1987 and Turneria Chatterjee and Small, 1989. Journal of Vertebrate Paleontology 14:142.

Chatterjee, S., and B. J. Small. 1989. New plesiosaurs from the Upper Cretaceous of Antarctica; pp. 197-215 in J. A. Crame (ed.), Origins and Evolution of the Antarctic Biota. Geological Society of London Special Publication 47, London.

Cohen, K. M., S. M. Finney, P. L. Gibbard, and J.-X. Fan. 2013. The ICS International Chronostratigraphic Chart. Episodes 36:199-204.

Conrad, J. L. 2004. Skull, mandible, and hyoid of Shinisaurus crocodilurus Ahl (Squamata, Anguimorpha). Zoological Journal of the Linnean Society 141:399-434.

Cope, E. D. 1869. Synopsis of the extinct Batrachia, Reptilia and Aves of North America. Transactions of the American Philosophical Society, New Series 14:1-252.

Cruickshank, A. R. I., and R. E. Fordyce. 2002. A new marine reptile (Sauropterygia) from New Zealand: further evidence for a Late Cretaceous austral radiation of cryptocleidid plesiosaurs. Palaeontology 45:557-575.

de Blainville, H. M. D. 1835. Description de quelques espèces de reptiles de la Californie précédé de l'analyse d'un système général d'herpétologie et d'amphibiologie. Nouvelles annales du Muséum d'histoire naturelle de Paris, Série 3, 4:233-296.

Druckenmiller, P. S. 2002. Osteology of a new plesiosaur from the Lower Cretaceous (Albian) of the Thermopolis Shale of Montana. Journal of Vertebrate Paleontology 22:29-42.

Fostowicz-Frelik, Ł. and A. Gaździcki. 2001. Anatomy and histology of plesiosaur bones from the Upper Cretaceous of Seymour Island, Antarctic Peninsula; pp. 7-32 in A. Gaździcki (ed.), Palaeontological Results of the Polish Antarctic Expeditions. Part III. Palaeontologia Polonica 60. Institute of Paleobiology of the Polish Academy of Sciences, Warsaw.

Gasparini, Z., and L. Salgado. 2000. Elasmosáuridos (Plesiosauria) del Cretácico Tardío del Norte de Patagonia. Revista Española de Paleontología 15:13-21.

Gasparini, Z., L. Salgado, and S. Casadío. 2003a. Maastrichtian plesiosaurs from northern Patagonia. Cretaceous Research 24:157-170.

Gasparini, Z., N. Bardet, J. E. Martin, and M. Fernandez. 2003b. The elasmosaurid plesiosaur Aristonectes Cabrera from the latest Cretaceous of South America and Antarctica. Journal of Vertebrate Paleontology 23:104-115.

Goloboff, P., J. Farris, and K. Nixon. 2003. T.N.T.: Tree Analysis Using New Technology. Program and documentation. Available at www. zmuc.dk/public/phylogeny. Accessed August 2014.

Goodrich, E. S. 1930. Studies on the Structure and Development of Vertebrates. Macmillan, London, $837 \mathrm{pp}$.

Hector, J. 1874. On the fossil reptiles of New Zealand. Transactions of the New Zealand Institute 6:333-358.
Hiller, N., and A. Mannering. 2004. Elasmosaur (Reptilia: Plesiosauria) skull remains from the Upper Cretaceous of North Canterbury. New Zealand. Records of the Canterbury Museum 18:1-7.

Hiller, N., A. Mannering, C. Jones, and A. Cruickshank. 2005. The nature of Mauisaurus haasti Hector, 1874 (Reptilia: Plesiosauria). Journal of Vertebrate Paleontology 25:588-601.

Ketchum, H. F., and R. B. J. Benson. 2010. Global interrelationships of Plesiosauria (Reptilia, Sauropterygia) and the pivotal role of taxon sampling in determining the outcome of phylogenetic analyses. Biological Reviews 85:361-392.

Lomax, D. R., and W. R. Wahl. 2013. A new specimen of the elasmosaurid plesiosaur Zarafasaura oceanis from the Upper Cretaceous (Maastrichtian) of Morocco. Paludicola 9:97-109.

O'Gorman, J. P., Z. Gasparini, and M. Reguero. 2010. Aristonectes parvidens Cabrera (Sauropterygia, Plesiosauria) from Cape Lamb, Vega Island (Upper Cretaceous), Antarctica. XXXI Scientific Committee on Antarctic Research (SCAR) Open Science Conference, abstract 557. 3-6 August 2010, Buenos Aires.

O’Gorman, J. P., Z. Gasparini, and L. Salgado. 2013. Postcranial morphology of Aristonectes Cabrera, 1941 (Plesiosauria, Elasmosauridae) from the Upper Cretaceous of Patagonia and Antarctica. Antarctic Science 25:71-82.

O'Gorman, J. P., Z. Gasparini, and L. Salgado. 2014a. Reappraisal of Tuarangisaurus cabazai (Elasmosauridae, Plesiosauria) from the Upper Maastrichtian of northern Patagonia, Argentina. Cretaceous Research 47:39-47.

O'Gorman, J. P., R. A. Otero, and N. Hiller. 2014b. First record of a juvenile aristonectine (Plesiosauria, Elasmosauridae) from the Upper Cretaceous Conway Formation of New Zealand, and the nature of the Mauisaurus haasti hypodigm. Alcheringa 38:504-512.

O’Gorman, J. P., L. Salgado, E. B. Olivero, and S. Marenssi. 2015. Vegasaurus molyi gen. et sp. nov. (Plesiosauria, Elasmosauridae) from the Cape Lamb Member (lower Maastrichtian) of the Snow Hill Island Formation, Vega Island, Antarctica, and remarks on Weddellian Elasmosauridae. Journal of Vertebrate Paleontology, e931285. DOI: 10.1080/02724634.2014.931285.

O'Keefe, F. R. 2001. A cladistic analysis and taxonomic revision of the Plesiosauria (Reptilia: Sauropterygia). Acta Zoologica Fennica 213:1-63.

O'Keefe, F. R., and H. P. Street. 2009. Osteology of the cryptocleidoid plesiosaur Tatenectes laramiensis, with comments on the taxonomic status of the Cimoliasauridae. Journal of Vertebrate Paleontology 29:48-57.

Otero, R. A., S. Soto-Acuña, and D. Rubilar-Rogers. 2012. A postcranial skeleton of an elasmosaurid plesiosaur from the Maastrichtian of central Chile, with comments on the affinities of Late Cretaceous plesiosauroids from the Weddellian Biogeographic Province. Cretaceous Research 37:89-99.

Otero, R. A., S. Soto-Acuña, A. O. Vargas, D. Rubilar-Rogers, R. YuryYáñez, and C. S. Gutstein. 2014a. Additions to the diversity of elasmosaurid plesiosaurs from the Upper Cretaceous of Antarctica. Gondwana Research 26:772-734.

Otero, R. A., S. Soto-Acuña, F. R. O'Keefe, J. P. O'Gorman, W. Stinnesbeck, M. E. Suárez, D. Rubilar-Rogers, C. Salazar, and L. A. Quinzio. 2014b. Aristonectes quiriquinensis sp. nov., a new highly derived elasmosaurid from the upper Maastrichtian of central Chile. Journal of Vertebrate Paleontology 34:100-125.

Owen, R. 1860. On the orders of fossil and recent Reptilia and their distribution in time. Report of the British Association for the Advancement of Science 29:153-166.

Pol, D., and I. H. Escapa. 2009. Unstable taxa in cladistics analysis: identification and the assessment of relevant characters. Cladistics 25:515-527.

Sato, T., X. C. Wu, A. Tirabasso, and P. Bloskie. 2011. Braincase of a polycotylid plesiosaur (Reptilia: Sauropterygia) from the Upper Cretaceous of Manitoba, Canada. Journal of Vertebrate Paleontology 31:313-329.

Sato, T., Y. Hasegawa, and M. Manabe. 2006. A new elasmosaurid plesiosaur from the Upper Cretaceous of Fukushima, Japan. Palaeontology 49:467-484.

Suazo, F., and R. A. Otero. 2014. Análisis gráfico bivariado de proporciones vertebrales dorsales en plesiosaurios elasmosáuridos del Cretácico Superior de Chile y Norteamérica: su valor diagnóstico para la identificación de aristonectinos adultos de gran tamaño. V Simposio - Paleontología en Chile, Libro de Resúmenes, p. 39. 3-6 October 2015, Valdivia, Chile. 
Vincent, P., N. Bardet, X. Pereda-Suberbiola, B. Bouya, M. Amaghzaz, and S. Meslouh. 2010. Zarafasaura oceanis, a new elasmosaurid (Reptilia: Sauropterygia) from the Maastrichtian Phosphates of Morocco and the palaeobiogeography of latest Cretaceous plesiosaurs. Gondwana Research 19:1062-1073.

Wegner, T. 1914. Brancasaurus brancai Wegner, ein elasmosauride aus dem Wealden Westfalens. Brancia Festschrift, Berlin:235-302.

Welles, S. P. 1943. Elasmosaurid plesiosaurs with description of new material from California and Colorado. Memoirs of the University of California 13:125-254.

Welles, S. P. 1952. A review of the North American Cretaceous elasmosaurs. University of California Publications in Geological Sciences 29:47-144.

Welles, S. P. 1962. A new species of elasmosaur from the Aptian of Colombia and a review of the Cretaceous plesiosaurs. University of California Publications in Geological Sciences 44:1-96.

Welles, S. P., and D. R. Gregg. 1971. Late Cretaceous marine reptiles from New Zealand. Records of the Canterbury Museum 9:1-111.

Wiffen, J., and W. Moisley. 1986. Late Cretaceous reptiles (families Elasmosauridae, Pliosauridae) from the Mangahouanga Stream, North
Island, New Zealand. New Zealand Journal of Geology and Geophysics 29:205-252.

Williston, S. W. 1890. A new plesiosaur from the Niobrara Cretaceous of Kansas. Transactions of the Kansas Academy of Sciences 12: 174-178.

Wilson, G. J., P. Schiøler, N. Hiller, and C. M. Jones. 2005. Age and provenance of Cretaceous marine reptiles from the South Island and Chatham Islands, New Zealand. New Zealand Journal of Geology and Geophysics 48:377-387.

Zinsmeister, W. J. 1979. Biogeographic significance of the Late Mesozoic and early Tertiary molluscan faunas of Seymour Island (Antarctic Peninsula) to the final break-up of Gondwanaland; pp. 349-355 in J. Gray and A. J. Boucot (eds.), Historical Biogeography, Plate Tectonics and the Changing Environment. Oregon State University Press, Eugene, Oregon.

Submitted March 17, 2014; revisions received December 10, 2014; accepted April 20, 2015.

Handling editor: Emily Rayfield. 